\author{
Kátia Santana Freitas², Igor Gomes Menezes ${ }^{3}$, Fernanda Carneiro Mussi ${ }^{4}$
}

\footnotetext{
${ }^{1}$ This study is a part of the project funded by CNPq - Edital Universal.

${ }^{2}$ Ph.D. in Nursing. Professor of the Health Department at Feira de Santana State University. E-mail: ksfenfpro@hotmail.com

${ }^{3}$ Ph.D. in Psychology. Adjunct Professor of Psychology at Federal University of Bahia (UFBA). E-mail: igmenezes@yahoo. com.br

${ }^{4}$ Ph.D. in Nursing. Associate Professor I of the Department of Medical-Surgical Nursing and Nursing Administration at School of Nursing. UFBA. E-mail: femussi@ufba.br
}

\begin{abstract}
This study aimed at understanding the meaning of comfort to the families of people in intensive care units. It consists of a qualitative study carried out in the intensive care unit of a hospital in Salvador-Bahia. Fourteen family members were interviewed. The authors utilized the theoretical principles of symbolic interactionism and the technique of qualitative data analysis. Results indicated that the categories Safety, Receptiveness, Information, Proximity, Social and Spiritual Support, Convenience and Integration expressed the meaning of comfort, which was comprised of reliability in terms of technical-scientific competence and a supportive and sensitive attitude of the team, chance of recovery, access to information and the opportunity to be close to the patient, support of people in their social life, spiritual sources and the environmental structure of the hospital, preservation of self-care and routine activities. It was concluded that the family is important as objects and subjects of the actions in healthcare and must be the focus in public health policies and programs in Brazil.
\end{abstract}

DESCRIPTORS: Family. Health care. Family nursing.

\title{
CONFORTO NA PERSPECTIVA DE FAMILIARES DE PESSOAS INTERNADAS EM UNIDADE DE TERAPIA INTENSIVA
}

RESUMO: O estudo objetivou compreender o significado de conforto para familiares de pessoas em Unidade de Terapia Intensiva. Trata-se de pesquisa qualitativa realizada na Unidade de Terapia Intensiva de um hospital, em Salvador-Bahia. Entrevistaram-se quatorze familiares. Recorreu-se aos pressupostos teóricos do Interacionismo Simbólico e à técnica de análise de dados qualitativos. Os resultados apontaram que as categorias Segurança, Acolhimento, Informação, Proximidade, Suporte social e espiritual, Comodidade e Integração consigo e o cotidiano expressaram o significado de conforto, que englobou confiança na competência técnico-científica e atitude solidária e sensível da equipe, chance de recuperação, acesso à informação e possibilidade de estar próximo do parente, apoio de pessoas do convívio social, de fontes espirituais e da estrutura ambiental do hospital e preservação do autocuidado e atividades habituais. Concluiu-se que a família é importante como objeto e sujeito das ações em saúde e deve ser enfocada nas políticas e programas de saúde pública no Brasil.

DESCRITORES: Família. Atenção à saúde. Enfermagem familiar.

\section{CONFORT EN LA PERSPECTIVA DE FAMILIARES DE PERSONAS EN UNIDAD DE TERAPIA INTENSIVA}

RESUMEN: Se objetivó con el estudio comprender el significado de confort para familiares de personas en Unidad de Terapia Intensiva. Esta investigación cualitativa fue realizada en la Unidad de Terapia Intensiva general de un gran hospital, en Salvador-Bahia, Brasil. Catorce familiares fueron sometidos a la encuesta. Se utilizó la teoría del Interaccionismo Simbólico y se empleó la técnica de análisis de datos cualitativos. Las categorías Seguridad, Acogida, Información, Apoyo social y espiritual, Proximidad, Comodidad e Integración consigo y con el cotidiano expresaron los significados de confort que involucró la confianza de la competencia técnico científica y actitud solidaria y sensible del equipo, oportunidad de recuperación, acceso a la información y posibilidad de acercarse al pariente, apoyo de personas del entorno social, de fuentes espirituales y de la estructura ambiental del hospital y preservación del cuidado personal y actividades habituales. Se concluye que la familia es importante como objeto y sujeto de acciones en salud y debe estar enfocada en las políticas y programas de salud pública en Brasil.

DESCRIPTORES: Familia. Atención a la salud. Enfermería de la familia. 


\section{INTRODUCTION}

Comfort has been considered a positive, multidimensional, subjective, dynamic experience, which is modified in time and space and results from the interactions established by the subject with himself, to those surrounding him and to the situations faced in the process of disease and health care. ${ }^{1}$

This phenomenon has been considered as a fundamental concept in the nursing practice and accepted as a desired result stemming from the care of the subject, who may be the hospitalized person or his family members. ${ }^{1-3}$ In this perspective, it consists of an objective to be reached by the practices in health and nursing and its promotion among families has become imperative, since the family is a system in which the hospitalized relative is a part of, and thus must be considered an integrating element of health care. ${ }^{1-2}$

Comfort promotion is related to the proposal of integral care, which indicates the need to ease the suffering of people in all contexts of health care, including the hospital scope. ${ }^{4}$ However, the biomedical model, dominant in the practice of health services, demands the rendering of services on a large scale and with high costs, which leads to the fragmented organization of the work process. This model has reached the family, since it commonly disregards their needs and the needs of their family members, which evidences the focus of the professional actions centered on the ill body. Comfort promotion requires that caregivers value the autonomy, beliefs and expectations of the family member related to the care of his relative. The family must be considered a subject in the relationships established between professionals and patients and, therefore, demands attentive listening and consideration of its subjectivity, which is the first step in respecting its autonomy. ${ }^{5}$

The literature points out that family members who have a hospitalized relative may find themselves biologically, psychologically and socially fragile, since illness and hospitalization constitute events that produce discomfort, including suffering and changes in roles and habits of daily life, as well as the uncertainty of recovery of the relative. In addition, the family becomes involved in health practices, with the rationale that supports their use and the institutional objects that may be sources of comfort or discomfort, depending on how these interactions are established and meant. ${ }^{2-4}$ Nevertheless, the lack of studies approaching the theme of comfort in the perspective of families in the intensive care unit (ICU), with a multidimensional perspective, is real. The literature addresses the meaning of the comfort construct comfort for people in the ICU; however, it is limited in terms of focusing on the families. ${ }^{3}$

Considering the lack of studies approaching this theme - the importance of comfort promotion as an objective of nursing care practices - the family must be seen as a subject in health practices embracing an integral view. With the conviction that the positive responses of the hospitalized individual to their treatment may result from the affectivity established in this social network, it becomes fundamental to answer the central question of this study: what is the meaning of comfort for families who are experiencing the hospitalization of a relative in an ICU? This understanding will allow us to reflect on the care provided to the patient's family, as well as guide the teaching, research and practices in nursing aimed at promoting comfort.

In this context, the constituted study purpose was to understand the meaning of comfort for the families of people experiencing a critical health condition who are hospitalized in an ICU.

\section{METHOD}

Considering that comfort and discomfort are products of interaction, understanding must be sought regarding the interactions of the person with himself and with those surrounding him during the treatment. ${ }^{1}$ Therefore, the perspective of symbolic interactionism was used in order to understand the meaning of comfort as a subjective state, in light of the interactions experienced by the family in face of situations of disease and treatment of their relative. The basic premises of this approach ${ }^{1,6}$ allow the understanding that the experience of comfort and/ or discomfort is associated with the interactions established by the person at certain moments, and to explain the experience as a process and result of these interactions. This approach also makes it evident that the meanings of comfort are presented and modified in the interactions established by the person in the experienced situations (to himself, to other beings, situations and objects), and that the action of people, related to comfort or discomfort, are based in the meanings he attributes to the people/ objects he interacts with. ${ }^{1}$

The study type is exploratory with a qualitative component, developed at the general adult ICU of a large public teaching hospital, located in the city of Salvador, Bahia, which only treats patients of the Single Health System. 
The participants were the families of adults hospitalized in the ICU who met the following inclusion criteria: 18 years or older; being the closest relative to the hospitalized individual (family bonds); having a relative in the ICU for more than 24 hours; and having the ability to report and verbalize the experience.

The study began after it was approved by the Committee of Ethics for the Analysis of Study Projects, in July 2009, under protocol CEP n ${ }^{\circ}$. $022 / 2009$. The aspects contained in Resolution no. 196/96 of the National Health Council were respected in order to guarantee the protection of the study participations.

Semi-structured interview was the technique used for data collection. The first part of this instrument contained closed-ended questions regarding sociodemographic data and the relationship of the family member to the hospitalized relative; the second part consisted of open and semi-structured questions, such as: what situations of comfort or discomfort have you experienced during the hospitalization of your relative in the ICU? What brings you the most comfort in the ICU?

The first approach to the family members was made before or after a visit to the hospitalized relative, in the waiting room of the ICU. After the study objectives were clarified, the authors invited the family member to participate in the study and verified their interest, after which a scheduled time was agreed upon for the interview. The interviews took place in the period between August and October 2010, in a private room of the ICU, and took place after the agreement and signature of the Free and Clarified Consent Form.

The interviews were recorded and were later fully transcribed. Their duration varied between 25 and 40 minutes. They were performed until data saturation was reached; in other words, until there were no new data, in parallel to the growing comprehension of the identified concepts (categories). The criteria to determine saturation consisted of a combination of the empirical limits of the data to the integration and density of the categories and the theoretical sensitivity of the analyst. ${ }^{7}$ Fourteen family members participated in the study.

The data related to the characterization of the study participants were analyzed as percentages and presented descriptively. The technique of qualitative data analysis was used to analyze the answers to the open questions. ${ }^{7}$ Thus, in the first stage of data analysis the answers obtained in the interviews were examined exhaustively, line by line, in order to extract the first codes. Through the comparison process, these codes were grouped by similarities and differences to form the categories. The abstraction reached in the stage of data analysis allowed the categories to receive their respective names, which represented the meanings of the codes they grouped. This was a careful analytical process, through which gross data were split, examined and compared internally, while concepts were identified, developed and named. Therefore, as the analysis advanced, the categories were built, recoded and compared internally. ${ }^{7}$ In order to maintain the anonymity of the family members, they were identified in the statements according to their order of participation in the study.

\section{RESULTS}

\section{Sociodemographic characteristics of the fa- mily members}

The fourteen family members interviewed were predominantly female $(64.3 \%)$, with the average age of $38.2 \pm 11.9$ years, a complete high school education $(64.3 \%)$, were married $(64.3 \%)$ and Catholic (57.1\%). As for their employment situation, $57.1 \%$ were employed and $14.3 \%$ unemployed. The monthly family income of $57.1 \%$ of the participants was lower than three minimum wages; for $35.7 \%$ monthly family income varied from four to five minimum wages, and $7.1 \%$ earned six to ten minimum wages. The prevalent family bonds to the hospitalized relative were: sibling $(35.7 \%)$, spouse $(14.3 \%)$, mother $(14.3 \%)$, child $(14.3 \%)$, other (uncle, nephew) $(14.3 \%)$ and father $(7.1 \%)$. Most family members did not have any prior experience with having a relative hospitalized in an ICU (71.4\%).

\section{Meaning of comfort in the perspective of family members of people in an ICU}

The understanding of the meaning of comfort took place with the analysis of the statements of the family members, which revealed the interaction established among the family members and the relative in a life-threatening situation in the ICU, the family and the hospital care team and the material elements of the hospital structure. Data analysis permitted the identification of seven categories that, in their group, expressed the meaning of comfort for the family members, namely: Safety, Receptiveness, Information, Social and Spiritual Support, Proximity, Convenience and Integration to themselves and the routine. 


\section{Safety}

This category showed that comfort meant the faith of the family members in the technical-scientific competence of the health team, as well as the possibility of recovery of their loved one as a consequence of being in "good hands" and in a place that offers resources for the necessary treatment, conditions that guarantee the survival of the relative. For the family members, comfort meant the perception that the relative was being well-treated by skillful and expert professionals, that the team acted immediately in order to meet the care and treatment needs of the relative, and observed him with attention and responsibility. Therefore, the interactions of the family members with technically and scientifically competent professionals, who are committed to the quality of the care they offer, promote comfort.

Comfort is seeing that the health team is taking care of my son, do you understand? This makes me feel comforted, calmer. On the day it happened, I arrived here at the hospital, and I was comforted because the service was fast (I 1).

They shower him, take care of his oral hygiene, put on lotion, they take care of him... he is clean. They are always watching him, giving his medicine at the right time, always thoughtful, right? (I 5).

Comfort is knowing that he is being well treated and it is possible to see that because he is clean, they change his clothes, it makes us feel more relieved. It is certainly not a complete relief, but we know he is being observed and monitored. This is the comfort (I 9).

Everything she needs the ICU provides. Intensive care, right? So I am really calm due to that, it brings comfort to me and to her [...] so I think this place gives comfort (I 12).

The most comfortable moment is when the doctor says he is reacting, getting better, and that he will get out of this situation (I 4).

Another meaning of comfort was attributed to the interactions of the family to the humanity of the hospital care team, which was expressed by the following described category.

\section{Receptiveness}

For the family members, comfort meant being well-received; that is, considered as a person of importance in the interpersonal relationships with the team members of the hospital care system. Therefore, in their perception it meant respect, acceptance and appreciation by the professionals, being heard and understood, perceiving that the people of this system cared regarding the suffering of the family and tried to minimize it. Comfort also meant kind service by the people at the hospital reception and in the ICU, being treated with calmness, greeted with a smile or approached with a conversation, receiving information in a kind and understandable way, perceiving good will and sincerity on the part of the professionals. The team attitude, by showing interest in their needs such as checking to see if they were ready for the visit, escorting them to the relative's bed, offering an explanation for delays in the visit and guaranteeing the restoration of the time lost provided comfort to the family members.

When you arrive there, they treat you really well; they give us a lot of attention. I just got here to reception, they are treating me well... They talk to us, they are really calm, thoughtful. It works by order of arrival, they call you, ask who the patient is, and take you to their bed, because you often do not know it (I 5).

The doctor who talked to me, explained it to me, she always gives me a word of comfort, even with the situation what it is, she does not hide it, she talks to me... this cheers you up, even knowing it is a difficult situation (I 6).

Last week he was having this sort of spit in his mouth. There were two girls, so I called one of them and she said: 'oh, that is normal, you just have to wipe it'. But the other girl got closer, cleaned him, told me it was normal and explained what was happening. And the other did not care, she just said: 'this happens. He just needs to be cleaned!' That upset me, I did not say anything, but it upset me. The other came to me, to him, and did everything. She was great! (I 2).

When we arrive, we are well received at the reception. The doctor updates us, explains it properly. The nurses are thoughtful of us too. Whenever I ask something, they answer it kindly, with no difficulties; I have never been treated badly or with ignorance. They always tell you good morning or good afternoon, try to get information on how my father is. When we are putting clothes on they always ask: 'are you ready?'. They are always kind and willing (I 6).

The meaning of comfort to the family was also associated with their ability to get needed information regarding their relative, as the category Information revealed.

\section{Information}

Comfort meant receiving information that allowed the family members to be aware of the health reality of their relative. It meant receiving clear, true and sincere information from the health professionals, which divulged the real health condition of the 
relative and the treatment he was receiving, as well as everything related to their clinical evolution and what would happen in terms of exams, transfers and eventual discharge from the ICU. It also meant having access to information either in person or by telephone, at least on a daily basis, both in the institutionally determined moments, for instance in the medical report, and when the family judged that further information was necessary.

In myopinion, a good explanation brings comfort (I1).

Comfort is when the doctor gives information to me, on how he is, on how he reacted, on whether he had a setback (I 4).

People are always giving information. Just now, the doctor talked to me, she explained it and she always has a word to comfort me, even in the face of a difficult situation, she does not hide things, she tells me... that cheers me up, even though knowing it is hard (I 6).

Everyday there is a medical report, a conversation about the patient; they tell me everything about him, what is happening to him, what his day was like, everything they are doing to him. We know it. She explains everything in the medical report, whether the kidneys have stopped working... or started working again (I 7).

The attention of the doctor after the visit, explaining to us what is happening, comforts us, even if this is a difficult situation! (I 9).

The support provided to the family by the hospital team was also associated with the meaning of comfort, as shown by the category Social and Spiritual Support.

\section{Social and Spiritual Support}

In the family's perspective, comfort meant receiving support from the family, friends and their religion. Social and spiritual support was related to the provision of support to the family members, aimed at providing conditions for them to express their feelings and emotions, thus enabling them to face the experience in a more positive way. The frequent presence of friends in their lives meant that they could obtain assistance for the resolution of common problems. They encouraged the family member to have more faith and hope, which were transmitted by words of consolation and prayers.

I know now that I have friends. They are there, by me side, giving me strength. It is times like these that we need a friend and, honestly, I never thought I had so many friends, people I did not even know well... are calling, asking for information, staying there with us, giving support (I 2).
The family acknowledged that the spiritual support and faith in a superior being provided comfort, because by having their beliefs strengthened, the hope in the recovery of their relative remained strong.

The suffering we see her going through... completely cut, every day that goes by they operate and they open her again and so it goes... sometimes we just feel like losing faith, but we cannot... there is so much faith we cannot lose it, she is coming back home... I have faith in God that she is coming back, because the way she is now is only by the hands of God (I 6).

The opportunity to remain close in proximity to the relative in the ICU was another source of comfort revealed by the family and expressed in this category.

\section{Proximity}

Comfort meant being together with the relative physically and emotionally, and enjoying the interaction established between them. Proximity also meant having the opportunity to verify, monitor and observe the relative's condition closely, identifying what his/ her needs are. It meant spending the day with the relative in the ICU or even in the waiting room, without a restriction on the number and times of visits, being with the relative at the determined time and having the visit started at the scheduled time. If comfort meant being together, this presence was strengthened when the relative hospitalized in the ICU was capable of interacting; in other words, listening and expressing himself and when his family members identified that he could perceive their presence by his side.

When I get here, I see my son sleeping and he cannot even look at me, it is a difficult situation... when he opens his eyes when I arrive it is a comfort (I 1).

I would like to come every half hour and see her, just keep looking at her, because then you feel calmer (I3).

Not being present the whole time is discomforting. If a companion could stay it would be more comfortable for us, for the entire family, knowing that there is someone with him, so that he can feel we are there for him. Because I believe he can hear me, when I talk to him I think he can hear, and if he could see his son there with him it would be a great comfort for the whole family (I 6).

If I could, I would stay here, to really see what is happening. If I could, I would stay the whole time, because I can only trust what I see. I do not trust just by hearing the doctor say: 'Oh, she is fine!' I really have to see it with my own eyes (I 10).

Elements of the environment and the physi- 
cal structure of the hospital institution were also objects of family interaction and were associated with the meaning of comfort, as revealed by the category Convenience.

\section{Convenience}

Convenience meant the comfort of access to a place to have a meal and get a drink of water, having appropriate accommodations to sit and even spend the night, having a restroom and a waiting room near the ICU and a television to watch at the hospital.

The area should be more comfortable, more pleasing to smell, and there should be a nicer chair. There should be a view that the person would feel glad to look at, because the person is there and soon he will have the surprise of seeing the patient who is there (I 13).

I arrived at the hospital in the morning, and there was no access to get in... I could not even get a badge to stay in the hospital... I had to stay outside, in front of the hospital on the bench, so I took a nap... (I4).

The meaning of comfort for the family members was also related to the integration to themselves and the routine, as described in the following category.

\section{Integration to themselves and to the routine}

Comfort meant the ability of the family member to take care of not only himself, maintaining the usual activities and family life, but also the relative in the ICU. Unfortunately, this comfort was rarely experienced by the family members because their attention was centered on the hospitalized relative and on the possibility of his/her loss and the demands of hospitalization. Having a relative in the ICU meant difficulty in maintaining the integration with themselves and their routine due to the compromised nature of their sleep, rest and nutrition and the continuity of the family life, activities and projects, as before the admission of the relative into the ICU.

When I get home and do not see my son (he is really close to me), I cannot sleep, I keep worrying, I cannot eat. I have already lost $5 \mathrm{~kg}$. After he went there I saw my weight and I almost could not believe it, it is really scary (I 1).

My life is not how it used to be. I wait for him to get home from work, take a shower, have dinner, go to school, and get back from school. I have to tell myself not to be nervous... I have not been to the gym; there is no logic in going to the gym with my son in this situation... I cannot eat well, just a little, and I sleep only a little (I 2).
I am not home, I am not with my daughter who is only eight years old. Sometimes I miss her... my children are grown up but they need a mother (I 10).

My life is a catastrophe. Before it was all about studying-I was studying to get into college, and now, it is not like I am giving up, but now my life has totally changed [...] if she was sick, she is being treated but in her situation, we do not know what might happen (I11).

\section{DISCUSSION}

Family members are predominantly women, young adults, married, followers of a religion, have completed their high school education, have a low monthly income and work. They were predominantly siblings, spouses, mothers and children of the hospitalized relatives. ${ }^{9}$

The study results expressed the meanings of comfort for family members who have a relative in the ICU. The identified categories characterized the multidimensionality of the phenomenon, as already verified by other authors, ${ }^{1,10-12}$ and expressed that the promotion of comfort requires sensitivity, rationality and material conditions in terms of the care provided to the family and their relative. The identified meanings of comfort also permitted the reinforcement of the idea that this phenomenon is a positive, subjective and dynamic experience that changes in time and space and results from the interactions established by the individual with himself, the environment, those surrounding him and the situations he faces. ${ }^{1}$

The Safety category evidenced that the family, by reacting to the risk to their relative's life, trusts in the medical-scientific rationality in the hopes that this will guarantee survival. In this context, comfort results from the trust in the technical quality of the service, which makes the ICU emerge not as a place destined for the end of life, but as the scene of possible recovery of the being's strength. ${ }^{1}$ The demonstration of technical efficacy is essential for the family's trust in the health team and, thus, for the promotion of comfort. Safety, which is considered to be a fundamental attribute of comfort promotion, derives from the relationship established with the ICU professionals during the hospitalization, going past the technological apparatus and the qualified team of the ICU to mean an essential source of safe care and "cure". Comfort derives from the conviction that the relative is in a place that offers the best conditions for recovery.

The Receptiveness category showed that comfort means the interaction with professionals who 
are sensitive to the family's needs. The attention provided by them allows the family to feel accepted and acknowledged as a participant in the care process of the relative. Receptiveness also meant the possibility of meeting an expectation or need expressed by the family in face of the disease and the hospitalization of the relative. This professional attitude is expressed by words and kind behavior, by the offer of help and information, and by the manifestation of concern for the well-being of the family. ${ }^{10,13}$

Among its numerous meanings, receptiveness in healthcare means " [...] attention, consideration, shelter, receiving, serving, giving credit to, listening to, admitting, accepting, taking into consideration, offering shelter, protection of physical comfort, having or receiving someone", 14:291 attributes of integral healthcare. Comfort, in terms of receptiveness, means trying to understand what the family members say and need. In order to do this, it is fundamental to have an authentic interest in listening to those whom we intend our good practices to help. Attentive listening constitutes an essential element for the promotion of comfort, as expressed by this category. The relational distance between the ICU professionals and the family may mean discomfort due to the lack of comprehension regarding the situation faced and the disregard of the importance of their participation in the care of their relative. Verifying the interest of the professionals in answering the family's questions favors the approach and, consequently, the comfort extended to the family. This is an important action in nursing. ${ }^{15}$

Comfort for the family meant being informed regarding the evolution of their relative's clinical condition. The information that was offered clearly and sincerely, allowing the family to understand the true condition of the relative, was considered to be a comfort, helping to minimize questions and, sometimes, the fear of uncertainty regarding the relative's destiny or the lack of control over the situation. This need is an important one, as families who are "surprised" by a complication in their relative's care may suffer undue distress. Nurses and other health professionals must anticipate information required by the family members. It is unnecessary to wait for it to be requested; rather, it is necessary to investigate whether they have the correct information and what they would like to know regarding the care and treatment of their relative and the ICU itself. ${ }^{13,16-18}$

Social and spiritual support constituted another meaning of comfort, showing that in situations of crisis significant people play important roles, taking care of children, guiding parents, helping in the performance of daily activities and helping to resolve everyday problems. Therefore, the family care becomes strengthened by the network of social support formed by relatives, friends and neighbors. ${ }^{19}$ In this perspective, the nurse can recognize that everyone involved requires support (not just the patient) and can use reason in the application of hospital routine and rules, aimed at ensuring that relatives can stay with their loved ones in the hospital. The search for spiritual support was also noted, and presented comfort to families. Several family members engaged in individual prayers, group prayers and promises to God.Studies show that spiritual and religious practices must be encouraged when the family finds them significant, since religiosity may be considered to be an individual psychosocial resource, becoming important for coping with situations of pain, suffering and death..$^{20-21}$

Comfort, according to the family members, meant being able to be close to their relative as much as possible. The presence of a family member with the relative, besides reflecting support and safety, may be a factor in improvement in the condition of the patient and quality of care provided in terms of risk prevention. ${ }^{13,17-18}$ Here, the authors reassert the idea of the importance of individualizing the hospital routines and rules in order to favor the visit of a relative whenever it is requested or it is perceived as necessary. Hospitalization in the ICU, besides generating a rupture in the family life, aggravates this situation when it restricts the proximity of the family member to the relative. The suffering regarding this separation cannot be eliminated, but it may be relieved by the constant ability of the family to establish a relationship of exchange and involvement with the relative. ${ }^{16}$

In the family members' views, comfort also meant Convenience; in other words, having quality surroundings and amenities within the hospital environment. Other studies pointed out that the waiting room was the place where families stayed the longest, since they wanted to be close to the relative and to feel useful. Therefore, it is necessary that this space be pleasant and provide appropriate accommodations. For this reason, it must be spacious, clean and private, with comfortable reclining chairs, especially for those who wish to spend the night. It must offer access to the Internet, restrooms, snacks and good communication with the ICU. ${ }^{10,18,21}$ It is possible to increase the comfort of family members by providing pleasant accommodations.

Comfort meant being able to take care of themselves and maintaining their regular lives, in 
spite of having a relative in the ICU. Nevertheless, the hospitalization of a relative generates changes in the dynamics of the family and personal life due to the intense anxiety and insecurity resulting from the disease and the absence of the relative in the routine of the family relationships, leaving a gap to be filled. ${ }^{21}$ This complicates life for the family members in meeting demands for personal care, as highlighted by the participants in this study, who described the following: lack of appetite, difficulty in resting due to the absence from home and tension and anxiety in face of the uncertainty regarding the relative's recovery. Studies have shown that lack of self-care is observed in family members, who suffer mainly from the loss of sleep, nutrition and sexuality. They also revealed that the family members who were most frequently absent from home worry about their house, are unable to relax far from their children, underestimate their own health problems, do not verbalize their anxiety and fears well and do not participate in leisure activities. ${ }^{19,21}$

It is inferred that the meaning of comfort related to the integration of themselves into the routine is difficult to translate into the experiences of family members with a relative in the ICU, but it is understood that promotion of social and spiritual support, receptiveness, proximity of the family to the relative, and security in the provision of care and information may, indirectly, contribute towards this integration.

The study results provide clear direction for the nursing team in terms of practices to promote the comfort of family members. Therefore, nursing professionals need to consider family members as also being under their care, and be attentive to the behavior, gestures, attitudes and forms of communication between themselves and the family members, since the interactions established may generate either comfort or discomfort. The approach and involvement offered to the family must be valued and may be facilitated by an empathetic and sensitive attitude towards the family. There resides a challenge to be achieved by the interdisciplinarity of health practices, by the adoption of a family focus in the scope of policies and programs in public health in Brazil, and by the incorporation of the family as both an object and subject of the health actions. Undoubtedly, the family must constitute a target for public policies so that human resources are qualified and made available at health institutions, aimed at minimizing the difficulties of integrating the family into the care unit. The education of the health professionals must be based on the biomedical model, distant from the relational and intersubjective universe of the family.

The revealed meanings of comfort showed that, for the promotion of comfort of family members to take place, the nurse(s) must act in an integrated way with the health team, proposing, carrying out and evaluating health care practices related to receptiveness, social and spiritual support and communication with the family. It is also important to point out to hospital administrators the elements of the hospital physical environment associated with the family's convenience and comfort (and those that are not). It is essential for the health team to receive technical-scientific education regarding new-generation technologies oriented to the rendering of safe care. Based on these recommendations, the health team may perform, in a consistent and grounded way, family care practices, thus obtaining success in comfort promotion.

\section{CONCLUSION}

The study aimed at identifying the meanings of comfort for family members with a relative in the ICU, who expressed themselves in six categories, namely Safety, Receptiveness, Information, Proximity, Social and Spiritual Support, Convenience and Integration to themselves and to the routine.

These categories showed that comfort meant confidence and faith in the technical-scientific competence of the health professionals; perceiving solidarity and a sensitive attitude of the people in the service system; having access to and being aware of the condition of the hospitalized relative; being close to the relative physically and emotionally; receiving help from people in their social life; having sources of spiritual support; enjoying the support of the physical and environmental structure of the hospital and being able to take care of themselves and maintain the dynamics of their daily lives.

The incorporation of the family as both object and subject of health actions, as well as the focus of the full scope of public health policies or programs in Brazil was considered important.

It is important to highlight as a possible limitation of this study its development in a restricted context; in other words, a single public ICU of a hospital located in the municipality of Salvador Bahia. The lack of literature on the family and comfort theme is evident, which hints at the need for the replication of this study with other population groups, at other public and private ICUs in Salvador and in other states of the country, so that it is possible to broaden 
the concept of comfort in the perspective of family members who experience the hospitalization of a relative in an ICU. The lack of studies of this nature may have limited the comparison of findings of this study. The authors also propose the construction of comfort indicators, aimed at measuring, in clinical practice, this construct to evaluate the effectiveness of the care provided to family members with a relative in a life-threatening situation.

\section{REFERENCES}

1. Mussi FC, Koizumi MS, Angelo M, Lima MS. Perda da espontaneidade da ação: o desconforto de homens que sofreram infarto agudo do miocárdio. Rev Esc Enf USP. 2002 Jun; 36(2):115-24.

2. Vaz DC, Silva CRL, Figueiredo NMA. A utilização da bibliometria na análise do referente conforto. Cogitare Enferm. 2010 Out-Dez; 15(4):736-41.

3. Apóstolo JLA. O conforto nas teorias de enfermagem: análise do conceito e significados teóricos. Rev Referência. 2009; II Serie (9):61-7.

4. Oliveira R, Maruyama SAT. Princípio da integralidade numa UTI pública: espaço e relações entre profissionais de saúde e usuários. Rev Eletr Enferm [online]. 2009 Mai [acesso 2010 Fev 01]; 11(2):375-82. Disponível em: ttp://www.fen.ufg. br/revista/v11/n2/v11n2a19.htm

5. Ministério da Saúde (BR), Secretaria executiva, Núcleo Técnico da Política Nacional de Humanização. Humaniza SUS: visita aberta e direito a acompanhante. Brasília (DF): MS; 2007.

6. Charon JM. Simbolic interactionism. $3^{\mathrm{a}}$ ed. Englewood Cliffs (US): Prentice-Hall; 1989.

7. Strauss A, Corbin J. Pesquisa qualitativa: técnicas e procedimentos para o desenvolvimento de teoria fundamentada. Porto Alegre (RS): Artmed; 2008.

8. Gutierrez DMD, Minayo MCS. Produção de conhecimento sobre cuidados da saúde no âmbito da família. Ciência Saúde Coletiva. 2010 Jun; 15(supl I):497-508.

9. Freitas KS. Construção e validação da escala de conforto para familiares de pessoas em estado crítico de saúde (ECONF) [tese]. Salvador (BA): Universidade Federal da Bahia, Programa de PósGraduação em Enfermagem; 2012.
10. Lourenço EC, Neves EP. As necessidades de cuidado e conforto de visitantes em UTI oncológica: uma proposta fundamentada em dados de pesquisa. Rev Bras Cancerol. 2008 Jul-Set; 54(3):213-20.

11. Malinowski A, Stamler LL. Comfort: exploration of the concept in nursing. J Adv Nurs. 2002 Sep; 39(6):599-606.

12. Kolcaba K. Comfort theory and practice: a vision for holistic health care and research. New York (US): Springer publishers; 2003.

13. Franco CM, Jorge MSB. Sofrimento do familiar frente a hospitalização In: Elsen I, Marcon SS, Silva MRS. $\mathrm{O}$ viver em família e sua interface com a saúde e a doença. Maringá (PR): Eduem; 2004. p.169-82.

14. Gomes MCPA, Pinheiro R. Acolhimento e vínculo: práticas de integralidade na gestão do cuidado em saúde em grandes centros urbanos. Interface Comunic Saúde Educ. 2005 Mar-Ago; 9(17):287-301.

15. Silveira AO, Angelo M. Interaction experience for families who lives with their child's disease and hospitalization. Rev Latino-am Enferm. 2006 NovDez; 14(6):893-900.

16. Siddiqui S, Sheikh F, Kamal R. What families want - an assessment of family expectations in the ICU. Int Arch Med. 2011 Apr; 4(21):1-5.

17. Silveira RS, Lunardi VL, Lunardi Filho WD, Oliveira AMN. Uma tentativa de humanizar a relação da equipe de enfermagem com a família de pacientes internados na UTI. Texto Contexto Enferm. 2005 Jul; 14(Esp):125-30.

18. Urizzi F, Corrêa AK. Relatives' experience of intensive care: the other side of hospitalization. Rev Latino-am Enferm. 2007 Jul-Ago; 15(4):598-604.

19. Souza AIJ. Cuidando de famílias: identificando ações de cuidado e não cuidado nos familiares. In: Elsen I, Marcon SS, Silva MRS. O viver em família e sua interface com a saúde e a doença. Maringá: Eduem; 2004. p.313-26.

20. Volcan SMA, Sousa PLR, Mari JJ, Horta BL. Relação entre bem-estar espiritual e transtornos psiquiátricos menores: estudo transversal. Rev Saúde Pública. 2003 Ago; 37(4):440-5.

21. Horn EV, Tesh A. The effect of critical care hospitalization on family members: stress and responses. Dimens Crit Care Nurs. 2000 Jul-Aug; 19(4):40-9. 